\title{
DIE RITUAAL VAN DIE NAGMAAL
}

Jan J. van der Walt

Departement Diakoniologie

Potchefstroomse Universiteit vir Christelike Hoër Onderwys

POTCHEFSTROOM

Abstract

THE RITUAL OF COMMUNION

Christian rituals are a two-way channel of communication, expnessing the believer's deepest hopes and proyers, and dramatizing God's promises and wamings. Thus the rituals in the Lord's Supper are of the greatest importance. The prayers, the meal with the sursum corda and the daxolozy are rituals through which communicotion is expressed between the Holy Trinity and the congregation. In this holy communion each Person of the Trinity has His own place and works according to the pactum salutis and the economy of the covenant in the Holy Trinity.

\section{AFGRENSING TOT DIE RITUAAL}

Hierdie artikel word, in aansluiting by die ander in hierdie uitgawe van KOERS, beperk tot die rituaal van die Nagmaalsviering. Met rituaal word die pakket van kerklike voorskrifte op Bybelse gronde vir die handelinge in die daadwerklike viering van die Nagmaal aangedui. Die meer algemeen gebruikte term ritueel word vermy omdat dit te formeel deur die rites bepaal word (HAT, 1988:906).

Wenham (1981:29) praat van "religious ritual in the Bible", met die omskrywing: "Like words, rituals are a two-way channel of communication. On the one hand they are dramatized prayers, expressing man's deepest hopes and fears; on the other hand they are dramatized divine promises or warnings, declaring God's attitude towards man." Hy vestig verder die aandag daarop dat die rituale in die Ou Testament "were so self-evident to the writers that they did not need to explain them" (1981:32). Rituaal is dus ten diepste kultureel-verbonde en berus op die nie-verbale boodskap/kommunikasie daarvan wat vir die betrokkenes onmiddellik verstaanbaar is. Ten opsigte van die Nagmaal wys Bieritz (1981:252) daarop dat brood en wyn kultuurprodukte is en nie natuurprodukte nie, wat weer die Nagmaal aandui as 'n gemeenskapshandeling en nie 'n blote voedingshandeling nie.

Die behandeling van die rituaal van die Nagmaalsviering word verder beperk tot die bekende Afrikaanse Nagmaalsformulier van die "Drie Afrikaanse Kerke" (Psalms, 1987:623).

Koers 55 (1990):179-195 
Die Nagmaalsformulier bestaan inhoudelik uit twee dele: die eerste deel is onderrigtend van aard en pastoraal van toon met opwekking, vermaning en troos; die tweede deel begin met die gebed en is gerig op die viering self en gee daarvoor die rituale aan as handelinge van God en handelinge van die gemeente (vgl. Bieritz, 1982:257).

Onder die liturgiese formuliere is die een vir die Nagmaal die mooiste, want "de woorden komen zo uit het evangelie. Zij stappen met kracht op de hoorders toe. Stijlverbetering of -vereenvoudiging bleek reeds vele malen een verarming" (Van 't Spijker et al., 1980:374). Desondanks word hierdie artikel beperk tot die rituale deel omdat werklikheid en skyn finaal skei in die viering self; omdat God in die Nagmaal die geestelike en hemelse lewe wat die gelowiges besit, voed en onderhou wanneer Christus geëet word (Nederlandse Geloofsbelydenis, artikel 35). Die gawe van God, wat Christus as 'n lewende brood aan gelowiges gee, en die opgawe aan die gelowiges om hierdie brood te eet, is nie leeg of tevergeefs nie terwyl dit ondeurgrondelik en onbegryplik is (Nederlandse Geloofsbelydenis, artikel 35). En die waarskuwing is nie lig of bangpratery nie: "Die goddelose mens ontvang wel die sakrament tot sy verdoemenis" (Nederlandse Geloofsbelydenis, artikel 35; vgl. Van der Wal, 1971:134).

Die rituaal is nie 'n formele ritus nie maar ' $n$ geloofsdaad wat deur bewustelike religie, deur die teologiese (leerstellige) denke en belewing van die Nagmaalsvierende, bepaal word. Tot die geloofsdaad kom selfs 'n gelowige nie sommer vanself nie. Daarvan getuig die formulier self met: "... dat ons daagliks moet stry teen die swakheid van ons geloof en ons sondige drifte". En daarmee eis die formulier, soos die Skrif, "selfondersoek". Die ou mens wat die gelowige nog afsterwe (Rom 6:2-11), is geneig "sich auf aussere Stützen zu verlassen" (Schuster, 1960:76).

\section{DIE NAGMAALSFORMULIER HET 'N SINVOLLE PLEK}

Daar was en is besware teen die gebruik van 'n formulier omdat dit "sleur, slenterdienst" (Van der Wal, 1971:172) in die hand sou werk; dan is daar nie meer troos of geloofsversterking in die Nagmaal nie, en 'n eerlike begeerte/verlange na die Nagmaal bestaan in der waarheid nie (vgl. Woelderink, 1946:357). Inderdaad, 'n formulier kán maklik in formalisme laat verval as liturg én lidmaat nie met geestelike inspanning betrokke en meelewend lees en luister nie.

Maar daar is ander gevare as formalisme en sleur. Een gevaar lè in die persoon van die predikant wat te oorheersend word (Van der Wal, 1971:173), en met sy persoonlike voorkeure oor die Nagmaalsgebruikers se sielservaring heers. Daar is midde in die gemeenskapsmaaltyd ook 'n allerindividueelste heilservaring. Die persoonlike geloofsbelydenis mag egter nie die verbondsgemeenskap verdring of ignoreer nie, sodat die 
Nagmaal 'n samevoeging van individue word nie. Dit bly eerstens God wat voedsel in die Nagmaal uitdeel sodat almal saam en elkeen afsonderlik daarvan ontvang en geniet (vgl. Van 't Spijker, 1980:59). Wanneer die eie geloofsdaad in die Nagmaal waaragtig is, sál die geloof die eenheid in Christus en die ware verbondsgemeenskap met die ander gelowiges herken, waardeer en met vreugde belewe as die eenheid wat die Heilige Gees smee (Ef 4:3). Op hierdie eenheid berus die Nagmaalsformulier en op die bevordering daarvan is die Nagmaalsformulier ingestel, terwyl dit alle ruimte laat om die Nagmaalsviering met 'n persoonlike geloofsbelewing te deurgloei. Daarom is dit nie 'n oop maaltyd nie, maar'n gemeenskapsmaal vir wedergeborenes (Nederlandse Geloofsbelydenis, artikel 35). Oor eeue heen het die formulier elkeen wat denkende, en nie meganies geluister het nie, gelei en gehelp om met verantwoording Nagmaal te gebruik terwyl die rituaal ingelei het in heerlike geloofsgemeenskap met Crod.

Ons Nagmaalsformulier is 'n kosbare erfstuk uit die Reformasie. Van der Wal (1971: 175), onder andere, gee 'n duidelike weergawe van die geboortegeskjedenis daarvan.

\section{DIE VOORGEBED IS 'N GEMEENSKAP MET DIE DRIE-ENIGE GOD}

Dit het 'n cliché geword om die Nagmaal slegs of sentraal op Christus te fokus: "Christus is die middelpunt" van die Nagmaal (Van der Wal, 1971:213); "maaltydgemeenskap met Christus as Gasheer" (Smit, 1982:12; Boelens, 1979:44); "de maaltijd van Christus" (Lammens, 1968:355).

Die gebed waarmee die rituaal van die Nagmaal betree word, het niks van "Christusmonisme" nie (Van 't Spijker, 1980:215; Van der Wal, 1971:215). Die drie-enige God is die middelpunt van die gebed en, gerig op die maaltyd wat volg, dui die gebed die drie-enige God aan as die middelpunt van die Nagmaal. In die gebed word die ekonomie (huishouding, onderlinge verhouding, samewerking) van die drie Persone in volle mate ooreenkomstig die Heilige Skrif eerbiedig. Nie een van die Persone word buite die verhouding met die ander of bó hulle gestel nie. Sonder die regte Godskennis waaruit die gemeenskap met God voortvloei, kan die Nagmaal nie ware suiwere geloofsversterking gee nie. En die formuliergebed wil juis die gelowige deur die Nagmaal tot geloofstoe-eiening lei deur hom daaroor te leer en daarvoor te laat bid.

\section{DIE AANROEP VAN DIE VADER AS DIE GASHEER}

In die aanspraak van die gebed rig die gemeente hom tot: "Barmhartige God en Vader". Uit die opvolgende "U geliefde Seun" blyk dat die eerste Persoon van die drie-enige God aangeroep word. Geheel en al in ooreenstemming met die Heilige 
Skrif word die Vader aanbid wat sy Seun gee tot versoening van ons sondes (Joh 3:16; 6:57; Rom 8:31,32). Nèrens in hierdie gebed word die Seun of die Heilige Gees aangespreek nie - heeltemal in die styl van die Onse Vader. Die inisiatief van die versoening word as die eie werk van die Vader geëer. En die doel - die belewing van versoening soos in die Nagmaal ervaar word, en waarvoor gebid word - is die sekerheid "dat U ewig ons genadige Vader is".

Daarom sluit die gebed aan by die onderrig dat "die toorn van God teen die sonde so groot (is) dat $\mathrm{Hy}$ dit, eerder as om dit ongestraf te laat bly, aan sy geliefde Seun, Jesus Christus, met die bittere en smadelike kruisdood gestraf het"; en onder "ten tweede" dat "die vaste belofte van God" geglo moet word; en onder "ten derde" dat "dankbaarheid aan God" betoon moet word. Die onderrig sluit dan met die Vader se keuring: "Almal wat so gesind is, wil God in genade aanneem en as waardige tafelgenote van sy Seun, Jesus Christus, beskou." In die hartsverheffing word die Nagmaalvierendes opgeroep om hulle harte na Christus, wat in die hemel is, op te hef omdat Hy "ons Voorspraak aan die regterhand van sy hemelse Vader is". Na Hóm, die Vader, voer die Nagmaal ons deur ons Middelaar, Jesus Christus.

Die gebed eerbiedig en begeer ook die werking van die Heilige Gees in die Nagmaal as 'n beskikking van die Vader: "U deur u Heilige Gees". Selfs die genade om getroos ons kruis op te neem, wat eie werk van die Heilige Gees is - met alles wat daarmee saamhang - word gevra as genade wat die Vader verleen.

Die werking van die Nagmaal om ons Christus en ook al sy weldade deelagtig te maak, om met Hóm gevoed en verkwik te word sodat $\mathrm{Hy}$ in ons en ons in Hom lewe, die verwerkliking van die verheerliking van ons liggame en om ewig by Hom te wees - dit alles word van die Vader gebid. "Achter het verzoenende werk van Christus staat de Vader" (Van 't Spijker et al.,1980:399).

Die slot van die gebed bevestig nogeens dat alles van die Vader gevra word: "Verhoor ons, o almagtige God en barmhartige Vader."

Hierdie gebed laat geen twyfel nie: die Nagmaal is die gawe van die Vader, Hy is die Gasheer. Christus en die Heilige Gees sal alleen volgens elkeen se eie werk, binne die ekonomie van die Drie-eenheid, en dus eiesoortig gasheer genoem kan word, maar nie in dieselfde sin van inisiërende Gewer as die Vader nie. Die klem in hulle werk lê op iets anders as om gasheer te wees. 


\section{GEBED OM CHRISTUS SE MIDDELAARSWERK}

Dit is wedergeborenes (Nederlandse Geloofsbelydenis, artikel 35) wat hier bid. Daarom is daar in die gebed die uitgesproke begeerte "om ons al meer aan u Seun oor te gee" (vgl. Joh 3:5,16,19). By die Nagmaal staan die geloof nie by 'n aanvangspunt nie, maar midde in 'n groeifase. Die gelowige lewe egter as 'n sondaar binne in 'n wêreld wat onder die las van die sonde sug (Rom 8:17-27). Wedergeborenes is nog onvolmaak, deur heiligmaking heen op weg na die heerlikmaking. Daarom lewe hulle met "belaste en verslae harte" as treurendes (Matt 5:4) en sugtendes (Rom 8:23) in swakheid (enkelvoud: áo日eveia, Rom 8:26). Hierdie swakheid is die gevolg van die deurwerking van die afbrekende krag van die sonde op die liggaam en siel (vgl. Lloyd-

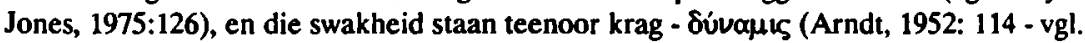
1 Kor 1:18,24). Teen hierdie swakheid is daar net een voedsel: on met "die liggaam en bloed, ja, met Hom, waaragtige God en mens, die enige hemelse brood ... gevoed en verkwik te word". Die voedsel bewerkstellig dat "ons nie meer in ons sondes lewe nie, maar Hy in ons en ons in Hom".

Met die gebed gaan die gelowige na die maaltyd om daarin Christus as Middelaar toe te ejen. Christus is die brood en drank in die maaltyd. Middelaar is sy heerlikheid en onmisbaarheid en eer, sy plek in die Goddelike ekonomie. Hiervoor het die Seun Homself gegee kragtens die pactum salutis (vgl. Jonker, 1977:188), die Trinitariese besluit tot die vleeswording van die Seun om ons Middelaar te wees. Daarmee het die Seun Homself tot voedsel in die maaltyd van die verbond aangebied. "Ek is die brood van die lewe" (Joh 6:48,52-56). In die Nagmaal gaan dit om lewe, die resultaat van glo (Joh 3:16).

Sy Middelaarskap en sy Gasheerskap in die Nagmaal is dus éen, en daarom onderskeie van die Vader van wie die Seun - ook as Middelaar - uitgaan. Daarom word verwarring liewer vermy en word Christus se eie werk en plek in die Nagmaal bely: $\mathrm{Hy}$ is die Middelaar, die brond en drank van die ewige lewe. Hy noem Homself in die kader van die Nagmaal: ì ó Srakovâv (Luk 22:27; vgl. Joh 13).

Die gemeente tree Hom in die gebed tegemoet met sy stem in hulle ore: "Die Vader het My lief omdat Ek my lewe afle om dit weer op te neem. Niemand neem dit van My af nie, maar Ek le dit uit my eie af. Ek het die volmag om dit af te lê, en Ek het die volmag om dit weer op te neem. Dit is die opdrag wat Ek van my Vader ontvang het" (Joh 10:17,18). Calvyn (1890:369) sê in sy kommentaar by hierdie woorde dat Christus ons voor die ewige raad van sy Vader stel om ons te laat verstaan dat die Vader ons saligheid so ter harte geneem het dat Hy sy eniggebore Seun geheel en al vir ons geskenk het. Hierby moet die vrywilligheid, die feit dat die Seun Hom "vir die Vader aangebied" het (Jonker, 1977:188) in volle berekening bly - "Ek le dit uit my eie af"! 
Die rituaal van die Nagmaal

Daarom is Hy Middelaar.

Die gebed begin met die sprekende dinamiese geloofsbelydenis: "In hierdie Nagmaal herdenk ons die heerlike gebeurtenis van die bittere dood van u geliefde Seun, Jesus Christus." In die enkele sin word met drie woorde die wesenlike van die Nagmaal omlyn: herdenk, heerlike gebeurtenis, bittere dood. Nagmaalvierend herdenk die gelowiges die eenmalige historiese gebeurtenis van Jesus Christus se dood, maar dan sy dood in die eenheid van sy ganse Middelaarswerk. Dit gaan om die "sacrificial act" (Cochrane, 1974:138). Die herdenking van sy dood omvat sy opstanding (1 Kor 15:428), want sy dood het alleenlik betekenis omdat Hy die dood oorwin het as die Lewende (Grosheide, 1932:506). Die dood van Christus op sigself maak wel vry van die hel, maar gee nog nie die ewige lewe nie (vgl. Calvyn, 1889:255). Daarom sê Hy: "tot My gedagtenis" en nie tot gedagtenis van my dood nie.

As Middelaar is Christus ons enigste Hoepriester wat Homself offer deur sy liggaam en bloed vir ons te gee tot ' $n$ versoening van ons sonde. Hy het as Middelaar, omdat $\mathrm{Hy}$ ons Hoepriester is, nie diere nie, maar Homself geoffer - "wat Homself deur die ewige Gees aan God sonder smet geoffer het" (Heb 9:14,15). "Ewige Gees" beteken hier nie die Heilige Gees nie, maar die Goddelike Gees, "die enige en enkelvoudige Wese wat ons God noem ... Ons staan hier by 'n geheim wat ons verstand te bowe gaan" (Jonker, 1977:185), naamlik die vereniging van die twee nature van Christus. Ons kan maar net saam met die Belydenis (Nederlandse Geloofsbelydenis, artikel 19) stamel: "Ware God om deur sy krag die dood te oorwin, maar ook ware mens om deur die swakheid van sy vlees vir ons te kon sterwe ... Hierdie twee nature is só saam in een Persoon verenig dat hulle selfs deur sy dood nie van mekaar geskei was nie." Andersins kan ons die Heidelbergse Kategismus antwoord 17 in ons hart en mond neem: "Om deur die krag van sy Godheid die las van die toorn van God aan sy mensheid te kan dra en vir ons die geregtigheid en die lewe te kan verwerf en teruggee." In die eenheid van sy Persoon dra sy Godheid sy mensheid deur die soenoffer heen tot in die heerlikheid van sy wederkoms (vgl. Alford, 1875:171; Grosheide, 1955:209,313; Stibbs, 1986: 1206; Guthrie, 1983:189; Calvyn, Institusie II, 12,3; Polman, s.j.:294).

Sy eenmalige offer gee Jesus in die Nagmaal aan sy dissipels. Wat Hy daar doen, doen Hy as Middelaar. Ons kan Hom met geen benaming méér maak as "die enigste Middelaar tussen God en die mense nie". Dat Hy Homself in brood en drank uitdeel, is net 'n voortsetting van sy Middelaarsdaad wat in die pactum salutis ontstaan het. Sy Middelaarskap omvat sy Gasheerskap in die Nagmaal. Wie hier skei, doen afbreuk aan sy Middelaarskap. Daarom eer en aanbid die Nagmaalsgebed Hom in sy Middelaarswerk: "Ons bid $U$ (dit is die Vader) ... sodat ons belaste en verslae harte met sy liggaam en bloed, ja met Hom, waaragtige God en mens, die enige hemelse brood, deur die krag van die Heilige Gees gevoed en verkwik word." 


\section{GEBED OM DIE VOED EN VERKWIK DEUR DIE HEILIGE GEES}

Die werk van die Heilige Gees, deur wie die Vader ons met Christus voed, ontvang in die Nagmaalsgebed ewe-eens sterk beklemtoning. Die werk van die Gees word na twee kante erken, én daarom gebid. Hy voed ons met Christus én Hy werk die geloof waarmee dié voeding ontvang (geëet) word (vgl. Heidelbergse Kategismus vraag en antwoord 76).

In ooreenstemming met antwoord 116 van die Heidelbergse Kategismus word tot die Vader gebid om die Gees. 'n Mens belewe in die Nagmaalsgebed iets van die "hartlike versugtinge" waartoe die Heidelbergse Kategismus, antwoord 116 vermaan.

Tog staan selfs die allerheiligstes onder die Nagmaalsgangers hier voor 'n misterie (vgl. Van der Wal, 1971:213; Cleason, 1983:291,292; Ridderbos, 1959:191). Wie hier nie verstom in verwondering nie, ervaar baie min van die Nagmaal. Die Gees is soos die wind. "There is a mystery about this; but it is a very real part of Christian experience." (Lloyd-Jones, 1975:137; vgl. Van der Wal, 1971:213; Bavinck, 1922:177.) Die gebed om die Gees is ook 'n gebed uit krag van die Gees wat ons laat bid. Agter die vurige Nagmaalsgebed om "U Heilige Gees" le die belydenis in die onderrigtende deel: deur die genade van die Heilige Gees het ons van harte berou oor ons gebreke en begeer ons om na al die gebooie van God te lewe. Daarom lei die Nagmaalsgebed ons in die bede om "deur die krag van die Heilige Gees gevoed en verkwik" te word "met Hom ... die enige hemelse brood". Die biddende begeerte ontspring uit die kennis "dat ons deur ons misdade dood is", en "dat ons daagliks moet stry teen die swakheid van ons geloof en ons sondige drifte".

Al die bedes wat tot die Vader gerig word om 'n aktiewe en groeiende geloof in ons, word gevra as werke van die Heilige Gees in ons: opregte vertroue, meer en meer oorgawe aan Christus, lewe in Christus en $\mathrm{Hy}$ in ons, sekerheid oor ons deel aan die genadeverbond, troos in die geloofstryd, vrymoedigheid om ons Heiland te bely, en blye sekerheid dat ons Heiland weer kom en ons altyd by Hom sal wees.

Die Nagmaalsgebed om die Heilige Gees is 'n gebed om ons Moeder.'

Die Onse Vader is nie slegs 'n slot van die gebed nie, maar is die samevatting van alles wat die gelowige in die Nagmaal verwag en verlang.

\footnotetext{
'Calvyn (Institusie III 1,4) noem die Heilige Gees, wat die oẻ van ons verstand open, die sleutel. Dit gaan by hom dus om geloofsinsig, terwyl die klem in die gebed tE op voed en verkwik, dit is op geloofsgroei.
} 
In die Nagmaalsgebed rig die gelowiges hulle tot die Vader en bid hulle om die volheid van die Middelaar te ontvang deur die onnaspeurbare, maar ervaarbare werk van die Heilige Gees "in hierdie Nagmaal". Dit is voluit Trinitaries en volledig volgens die ekonomie van die Triniteit.

\section{DIE UITNODIGING AAN GELOWIGES}

Die Nagmaalsformulier bevat nie 'n uitnodigingsformule nie. Die onderrigtende deel laat egter geen twyfel nie oor wie "God in genade wil aanneem en as waardige tafelgenote van sy Seun, Jesus Christus, beskou" (Psalms, 1987:618) nie. Die vorige formulier (Psalms, 1968:131) noem "waardige deelgenote van die tafel van sy Seun". Daar is ' $n$ aansienlike betekenisverskil tussen "waardige tafelgenote" en "waardige deelgenote van die tafel". Die eerste beteken mense wat saam met Jesus eet; die tweede kan net verstaan word as mense wat eet van die tafel/maaltyd wat die Seun voorsien, dit wil sê: sy Middelaarswerk. In die lig van die hele Nagmaalsformulier is laasgenoemde die korrekte vertaling van die oorspronklike: "medegenoten van de tafel" (vgl. Rutgers, 1913:88).

Wie is die waardige deelgenote van die tafel van Jesus Christus? Die stelling dat die Vader hulle "in genade aanneem" sluit alle verdienste-waardigheid uit; hulle waardigheid is hulle bewuste onwaardigheid. Dit blyk uit die omskrywing van die drie regte gesindhede ("Almal wat so gesind is"):

- Elkeen wat hom oor sy sonde en vervloeking mishaag en daaroor voor God verootmoedig.

- Elkeen wat die vaste belofte van God glo dat sy sonde hom alleen op grond van die lyding en dood van Jesus Christus vergewe is.

- Elkeen wat met sy hele lewe ware dankbaarheid aan God wil betoon en ware liefde aan sy naaste.

Dit is duidelik dat die uitnodiging gerig is tot hulle wat honger en dors na die geregtigheid is (Jes 55:1-3; Joh 7:37-38; Matt 11:27-30). In die praktyk word die uitnodiging uitgespreek onder verantwoordelikheid van die kerkraad met bediening van die Woord. Dan nooi God. Meestal word Jesaja 55:1 of vers 1-3 of Matteus 11:2730 of Johannes 6:54-57 as uitnodigingswoord gelees. 


\section{DIE BEDIENINGSWYSE}

Met die bedienigsformules word die bediening self, die daadwerklike Nagmaalsviering, naamlik die maaltyd, bereik. Die Gereformeerde Kerke se geskiedenis getuig van ruimte en vryheid ten opsigte van die middelmatige sake (vgl. Calvyn, Institusie IV, 18,43; Van't Spijker, 1980:129; Van der Wal, 1971:219; Van der Leeuw, 1949:342; Gereformeerde Kerke in Suid-Afrika Kerkorde artikel 62; Vyfde Algemene Sinode van die Gereformeerde kerke in Suidelike Afrika, 1988, notule, artikels 38,39).

Die formules by die uitdeel van die brood en die beker berus op die weergawe van Paulus in 1 Korintiërs 11:23-26. Daaraan is toegevoeg: "gedenk en glo". Die gelowige is dus nie 'n passiewe ontvanger aan die maaltyd nie. Van hom word die dinamiese geloofsaktiwiteit van 'n wedergeborene gevra (vgl. Nederlandse Geloofsbelydenis artikel 35; Dordtse Leerreëls IV, 16; Joh 3:16,19). Ware geloof mag nie passief wees nie, maar dit kan "veragter" (Heb 12:15), "moeg wees" (Matt 14:31). Of om in die taal van die Dordtse Leerreëls te praat: "Hulle wat die lewende geloof in Christus, die vaste vertroue, die gewetensrus, die beoefening van kinderlike gehoorsaamheid en die roem in God deur Christus nog nie ten volle ervaar nie - ofskoon hulle die middele gebruik waardeur God hulle beloof het om hierdie dinge in ons te bewerk - moet nie mismoedig word nie ... maar ywerig voortgaan om die middele te gebruik, vurig verlang na die tyd van oorvloediger genade en dit ook met eerbied en ootmoed verwag" (Dordtse Leerreëls, 1,16).

Teen die agtergrond praat die Nagmaalsgebed van "ons aan U Seun, Jesus Christus hoe langer hoe meer oorgee" (Psalms, 1968:135). Juis deur die Nagmaal kom God ons stompsinnigheid en swakheid te hulp deur ons te versterk in die toe-eiening deur geloof. Eet is toe-eienend glo. "Soo is dan het eten een vrucht ofte werck des gheloofs." (Calvyn, 1890:226; vgl. Heidelbergse Kategismus vraag 76).

Die breking van die brood was 'n gewigtige verskilpunt tussen Luther en Calvyn, soos Nischan (1984:17-29) duidelik aantoon. Die Nagmaalsformulier is opgestel ooreenkomstig die standpunt van Calvyn. Daarom dui die breking nie slegs ' $n$ wyse van uitdeling aan nie, maar is die bedoeling daarmee om die dood van Christus aan te dui, sonder om 'n letterlike breek van sy liggaam aan die kruis te impliseer (vgl. Joh 19:33,34). Volgens Calvyn (1889:176) was dit gedurende die eerste drie eeue in die Christelike kerk die gewoonte dat elkeen tydens die Nagmaal uit én brood sy stukkie uitbreek om daarmee die eenheid van alle gelowiges in die een liggaam van Christus voor te stel. Dit is ' $n$ vraag of die broodteken in die vorm van 'n bord vol blokkies nog die nie-verbale betekenis van $E k$ is die brood oordra. 
Die geloofshandeling in die Nagmaal (eet en drink) is selfstandige geloofsvolwasse toeeiening van Christus en gemeenskap met mekaar. Ná die uitdelingsformules swyg die formulier. "De dienst des Woords is achter de rug, nu wordt de maaltijd gevierd." (Lammens, 1968:379.) Van der Wal waarsku ook teen die gevaar dat die predikant te veel op die voorgrond tree en nou nog - in die maaltyd self - met sy persoonlike voorkeure die geloofsdaad van die geloofsvolwasse Nagmaalvierende(s) oorheers (1971:173). "Uiterst gelovige concentratie is hier eis." (Van 't Spijker et al., 1980:409.) 'n Geloofsvolwassene moet ondanks sy swakheid nie in die maaltyd nog aan 'n soogmoeder behoefte hê nie, want dan sal hy sy swakheid bestendig in plaas daarvan om daaruit te groei tot vaste geloofsekerheid. 'n Liturg wat die Nagmaal begryp, sal nie die Nagmaalvierendes tydens die maaltyd - terwyl hulle eet en drink met die duidingswoorde én die sursum corda in hulle gedagtes! - nog wil soog nie. Skriflesing onder die maaltyd kan verval (Lammens, 1968:379). Die waarskuwende woord is hier van pas: "Met de hoogkerkelijkheid heeft men gemeen, dat de voorganger meer solist is dan dirigent." (Lammens, 1968:345.)

Nagmaal word nie gebruik as 'n pleit om wedergeboorte nie, maar as 'n wedergeborene (Van Staden, 1982:36).

Die vroeë kerk het sewe handelinge gehad in die bediening van die Nagmaal: neem van die brood, danksegging, breking, uitdeling met duidingswoord, neem van die beker, danksegging, uitdeling met duidingswoord (Dix, 1960:48). Lammens en Dix bepleit 'n terugkeer na hierdie patroon, maar maak nie 'n voorstel hoe die danksegging moet lui nie (Lammens, 1968:354,355; Dix, 1960:48).

Die volgende voorstel vir 'n bewoording van die danksegging word in die midde gelê: Die uitdeling moet ná die duidingswoord plaasvind, en die duidingswoord moet vooraf. gegaan word met byvoorbeeld: "Ons dank U vir die brood van die lewe" (Joh 6:54); "Ons dank U vir die beker van die nuwe lewe" (vgl. Matt 26:28). Hierdie voorstel bevat verwante Skrifwoorde en is daarom in lyn met die duidingswoorde.

\section{DIE MAALTYD}

Daar is diegene wat die fisiese tafel so hoog ag dat die maaltyd verdwyn. Burnet (1960:293) wil "an uninterrupted view of the table" he "as it is the symbol of our worship". Tog is daar onder Gereformeerdes grootliks konsensus dat die tafel slegs die draer van die maaltyd is (vgl. Sinode, 1988, artikel 38,39 ) en dat die maaltyd wesenlik die Nagmaal is. 
Jesus sluit met die maaltyd aan by die Ou-Testamentiese assosiasies en voer dit deur in die gewone maaltydgemeenskap met sy dissipels, asook met tollenaars, sondaars en fariseërs. Die maaltyd was teken van sondevergiffenis, aanvaarding en heil (Smit, 1982:12). Omdat Hy Homself in die Nagmaal tot maaltyd gee, neem Hy nie self deel aan die maaltyd nie (Matt 26:26,27; Luk 22:15-20). Hy is die maaltyd.

Nêrens is die eenheid van 'n familie so sterk belewe as in gesamentlike maaltye nie. Met gesamentlike maaltye is besondere geleenthede gevier. "Mahlhalten ist mehr als sich sattessen, ist mehr als der Vorgang leiblicher Stattigung. Mahlhalten ist ein Grundvorgang menslicher Kommunikation, vertrauenvoller Gemeinschaft. Das Abendmahl ist ein Mahlzeit: Diese Satz besagt demgegenüber dass das Gedächtnis des Hernn nicht wie ein Mahlzeit - in Analogie zu sonstigen Essen und Trinken sonder als Mahlzeit begangen wird." (Bieritz, 1981:251,252; vgl. ook Rouillard, 1979:40-43.) Die ernstige vraag is of in ons alledaagse lewe die maaltyd - eet en drink in die Nagmaal - nie as onmiddellik verstaanbare teken met nie-verbale kommunikasie tot so 'n mate 'n erosie ondergaan het dat die teken sodanig besig is om te verdof dat 'n geloofwaardigheidsverlies ("Plausibilitătsverlustes" - Bieritz, 1987:795) van die Nagmaal die toenemende en skadelike resultaat is nie. In hulle gesprek oor die Nagmaal bevestig van Leeuwen en Hartveld (1971:57) die konsepsie dat eet en drink "consumeren van calorieën" geword het, en dat in die meeste gesinne nog "misschien wat heimwee!" na die oorspronklike betekenis van maaltyd lewe. 'n Mens sal werklik baie selfgenoegsaam moet wees om te dink dat hierdie teken-erosie van 'n maaltyd slegs in Duitsland en Nederland, en nie in Suid-Afrika nie, plaasgevind het nie.

Tog vier die kerke Nagmaal met die pretensie van 'n maaltyd. Soos Van der Leeuw (1949:342) sal weinig gelowiges, wat dié tradisie nog belewe, die aansit om 'n gedekte tafel wil verloor. Of die tradisie (die "heinwee") soos dit tans prakties nagekom word, sterk genoeg is om in die Nagmaal die nie-verbale boodskap van 'n maaltyd deur te gee, is al meer en meer 'n vraag: 'n Nagmaalsbediening met vyf en meer (tot sestien!) tafels (bedienings) skep gejaagdheid wat wesenlik in stryd is met die gemeenskapsoefening in 'n maaltyd en die nadink ("gedenk") ondermyn; dit skep'n gevoel van verveling by dié wat op 'n beurt wag of ná 'n beurt wag op die danksegging; dit skep verbreking van die eenheid van die liggaam (gemeente) in groepies; dit skep vervaging van die oproep tot die hartsverheffing. Die ergste is dalk dat in baie gemeentes as gevolg van voorgaande negatiewe elemente, so baie Nagmaalsdeelnemers die erediens (moet?) verlaat regstreeks na hulle beurt aan die tafel. Onder sulke omstandighede bly van die karakter van 'n maaltyd weinig behoue. 
Diep en indringend en vry van tradisie-verslawing sal die Bybelse begrip van 'n maaltyd én die nie-verbale boodskap daarvan in die lig van 'n eietydse maaltydbeskouing en maaltydbelewenis oorweeg moet word as Nagmaalsgebruik van betekenisloosheid, formalisme en eie-styl-stagnasie gered wil word, en betekenisryk in heilige gemeenskap Nagmaal gehou wil word.

Hiermee hang ten nouste saam die frekwensie van die Nagmaalsviering wat in ons tyd van vervreemding binne gemeentes (onbetrokkenheid, gebrek aan kotvwvia) al dringender ernstig word (vgl. Van der Merwe, 1976:31,54; Hutchins, 1972:68,69). Dit verdien ernstige oorweging om Nagmaal elke Sondag in die aanddiens saam met die prediking van die Geloofsleer (vgl. Kerkorde, artikel 68) te vier; dit verdien ook ernstige aandag om Nagmaal, ten minste soms, aan 'n gemeente-ete te verbind. Teken en betekenende saak moet ook ten opsigte van die maaltyd behoue bly (Calvyn, Institusie IV, 17,11 en 12).

Bavinck (1922:170-178; vgl. Cleason 1983:293-295) wys daarop dat Christus nie sy Gees of sy Godheid tot maaltyd gegee het nie, maar sy liggaam en sy bloed. Daarmee is $\mathrm{Hy}$ by die instelling van die Nagmaal die Middelaar en "dienskneg" (Luk 22:27). Daarom gaan dit nie in die Nagmaal bloot om 'n dogma of 'n verbale verkondiging nie, en volstaan die gelowige nie bloot met'n geloofsbelydenis nie. Die maaltyd druk uit dat die geloof kom tot toe-eiening. "Eet" en "drink" is werke van geloof (vgl. Jak 2:19-22).

\section{DIE HARTSVERHEFFING}

In die Nagmaalsformulier gaan die oproep tot hartsverheffing, sursum corda, ${ }^{2}$ die bediening van die maaltyd vooraf. Die bedoeling is dat die geloofsdaad van hartsverheffing in die maaltyd moet gebeur, want dan eers is daar werklike wesenlike Nagmaalsviering: "Om dan nou met die ware hemelse brood, Christus, gevoed te word moet ons nie met ons harte aan die sigbare tekens van brood en wyn verkleef bly nie maar ons harte ophef na die hemel waar Jesus Christus, ons Voorspraak aan die regterhand van sy Vader, is." Dit is verblydend ${ }^{3}$ dat die verkorte Nagmaalsformulier uitdruklik sè die sursum corda moet by die tafel ${ }^{4}$ gelees word (Psalms, 1976:63). Moet dit nie ook by elke sitting, soos die duidingswoorde, herhaal word nie?

\footnotetext{
${ }^{2}$ Lammens (1968:346) gee 'n goeie beskrywing van dic herkoms.

${ }^{3}$ Ondanks die aansienlike verarming wat andersins ingetrce het.

${ }^{4}$ Tog jammer dat dic hartsverheffing hier so wesentlik verkort is.
} 
Hieroor kan Calvyn (1889:199) maar weer aan die woord kom: "Want dewijl het nachtmaal een hemelsche handeling is, zoo is het geenszins ongerijmd, dat Christus in den hemel blijvende, door ons ontvangen wordt. Want dat Hy Zichzelven aan ons mededeelt, dat geschiedt door de verborgen kracht des Heiligen Geestes, waardoor de dingen, die naar de plaats wijd van elkaar zijn, niet alleen verzameld, maar ook samen tot één vereenigd worden. Maar opdat wij aan deze gemeenschap deelagtig zijn mogen, moeten wij tot den hemel ons verheffen. Hier moet ons dan het geloof te hulp komen, dewijl alle zinnen des vleesches bezwijken. Als ik zeg, geloof, zoo versta ik niet allerlei meening, die op menschelijke verdichtselen steunt, gelijk velen dikmaals van het geloof roemende, grootelijks in dit stuk dwalen. Hoe dan? Gij ziet het brood, en niets anders: maar gij hoort, dat het een teken des lichaams van Christus is: twyfelt niet dat door de Heere vervuld wordt, wat de woorden doen horen, te weten, dat het lichaam, dat gij niet ziet, u een geestelijk voedsel is. Het schijnt ongeloofelijk, dat wij door het vleesch van Christus gevoed worden, dat zoo verre van ons verwijderd is: bedenkt dat het een verborgen en wonderlijk werk des Heiligen Geestes is, dat gij niet met de mate van uw verstand behoort te meten ... Laat Hem in zijn hemelsche glorie blijven, en heft uw gemoed daarhenen op, opdat Hij vandaar u Zijner deelachtig make."

Met die hartsverheffing staan ons vierkantig voor die Nagmaalsgeheimenis. Die formulier redeneer nie, maar lei ons met die rituaal eenvoudig die hemelse heiligdom in "daar waar Christus is" (vgl. Heidelbergse Kategismus antwoord 76(d) en 80(d)). En die hartsverheffing word nie gedoen bloot om by Christus te kom nie, maar om in Christus, ons Voorspraak, by die Vader te kom. Die ware geloof vind sy rus nie finaal in die soteriologie nie, maar in soli Deo gloria, in alle eer aan God. S6 is die krag van Christus se eenmalige dood in die verlede, in die Nagmaal vir ons vars en lewend.

\section{LOFVERHEFFING}

Vir die eerste keer word die gemeente regstreeks in die rituale deel aangespreek: "Geliefdes in die Here". Hierdie aanspraak is eensluidend met dié wat in die onderrigdeel voorkom.

Die benamimg waarmee 'n liturg 'n gemeente aanspreek, is leerstellig en kommunikatief en pastoraal-empaties van groot belang, want daarmee word 'n evaluering van die gemeente uitgedruk. Paulus gebruik in sy Briewe altyd 'n innige aanspraak wat betrokkenheid (Kotvwvia) weergee, selfs al spreek hy daarna skerp vermanings uit (vgl. 1 Kor 
1:2). Bewus of onbewus, 'n neutrale aanspraak "gemeente" kom koud en uit die hoogte voor, en is sonder erkenning van die verbondenheid van die gemeente met die Here.

Daarom is dit nie betekenisloos dat die gemeente as "geliefdes in die Here" tot die lofverheffing opgeroep word nie. "Die Here" is hier, soos in die gebede, die Vader, want ná Psalm 103, 'n deel van die lof, volg: "Hy het selfs sy eie Seun nie gespaar nie." In die lofverheffing spreek geloof wat "in hierdie Nagmaal" vernuut is. Omdat gelowiges swak is en hulle geloofstoe-eiening nie altyd die (volle) rykdom van God se gawe in die Nagmaal eet en in hulle harte opneem nie, wissel die intensiteit van die lofverheffing tussen gelowiges en by dieselfde gelowige tussen geleenthede. Hieroor moet die gelowige nie moedeloos word nie, maar volhard in die stryd met Romeine 8:26,27 as versekering in sy gedagtes, en met Psalm 5:1 in sy hart:

\section{U weet wat in my woel en smeek; my sugte, as spraak nog ongebore is nie verlore.}

Van 't Spijker gaan te ver in sy tegemoetkoming aan die wat "in hierdie Nagmaal" nie die seëninge na verwagting ervaar nie. Hy sê: "Avondmaalsviering kan immers ook ná het avondmaal plaats hebben." (Van 't Spijker,1980:132.) Dat die betekenende saak vóor en ná Nagmaal daagliks in die gelowige se lewe moet plaasvind, is uit Johannes 6 onomwonde duidelik. Die Nagmaal is alleen 'n genadevolle versterking, wat as God se gawe nooit leeg is nie, maar aan ons kant daartoe dien om voortdurend te doen wat ons moet doen. Jesus sê: "Soos die lewende Vader My gestuur het, en Ek deur Hom lewe, so sal hy wat My eet, ook deur My lewe." (Joh 6:57.) Die "troos" van Van 't Spijker word problematies as hy voortgaan: "Wie op een onmiddellijke gevoelsmatige vorm van zegen zou wachten, hetzij als troost of vrede, hetzij als een bijzondere beslissende ervaring die toerust tot de strijd, die kon wel eens teleurgesteld worden. Het genadeverbond werkt krachtig. Maar het werkt nie magisch." (Van't Spijker, 1980:132.) Daar kom wel iets versagtends en versigtigs na vore in die woorde "kon wel eens", en as dit bedoel om te sê: vanweë ons swakheid werk die Nagmaal nie elke keer voluit en ryklik in ons geloofslewe in nie, dan word Van 't Spijker se waarskuwing/vertroosting begrypbaar. 'n Algehele afmaak van die verwachting van "een onmiddellijke gevoelsmatige vorm van zegen" en "een bijzondere beslissende ervaring van toerust tot stryd" asof daarin 'n evaluering van Nagmaal as iets magies, tooragtig sou wees - nee, dit gaan te ver, want dit ontken dat die Heilige Gees kragtig werk "in hierdie Nagmaal" en nie eers ná die Nagmaal nie. As die Nagmaal uitwerkingloos by 'n mens verbygaan, lê die fout in klein- of swak geloof. Die gebed verwag die werk van die Gees as 'n ervaring, 'n ervaring vol gevoelbelewing: "opregte vertroue in ons harte"; "om ... ons 
oor te gee"; "genadige Vader ... geliefde kinders"; "getroos ... verloën; "droefheid ... verlange".

Dit is waar (!), die Nagmaal werk nie magies nie. Die Nagmaal werk ook nie meganies sonder ' $n$ lewende geloof by die Nagmaalsvierende nie. Die Nagmaal werk wel onmiddellik, "in bierdie Nagmaal", daarom word dit deur gelowiges opgevolg met "aangesien die Here ons siele nou ... gevoed het" (beklemtoning toegevoeg). Ons moet nie so skrik vir die dwalinge van magie, piëtisme en mistisisme dat ons agterbly met 'n Nagmaal wat verarm en verskraal is, omdat ons die onmiddellike krag van die Heilige Gees nie verwag nie, daardeur nie bewoë word nie en nie verwonderd staan midde in die misterie van die ervaring nie (vgl. Bavinck, 1922:182,183). Van 't Spijker is te goed bekend om hom van so 'n oorreaksie te verdink, maar sy toegif kan voorstanders vir dié tendens, wat wél bestaan, wettigheid laat veronderstel. Geloof, én daarom Nagmaalsviering, sonder ervaring en gevoel is meganies, intellektualisties - kurkdroog, doods en verdor. Piëtisme en intellektualisme is ewe gevaarlik; gevoel en begrip is ewe noodsaaklik. "Wie de vergeving gelooft en daarom aanvaardt en ervaart vind ook al de andere goederen met Christus." (Van 't Spijker et al., 1980:416.)

\section{SLOTGEBED}

Wie gelowig Nagmaal gebruik het, dank. Soms is dit 'n hoë gloed, soms 'n rokende lamppit, maar die gelowige kan nie sonder dankgebed by "die heerlike gebeurtenis van die bittere dood" van sy Saligmaker verbygaan nie.

Die inhoud van die voorgebed én die Nagmaalservaring, keer nou dankend tot God. Hy het gegee, die gemeente is met Christus gevoed en is $\mathrm{H} 6 \mathrm{~m}$ met sy weldade deelagtig. In die voorgebed is gebid dat die Vader deur die Heilige Gees "'n opregte vertroue in ons harte sal bewerk". In die dankgebed word gebid dat die Vader deur die Heilige Gees "die gedagtenis van ons Here Jesus Christus en die verkondiging van sy dood bevorderlik wil laat wees vir ons daaglikse vooruitgang in die regte geloof en die salige gemeenskap". Alles is nie in die Nagmaal afgehandel nie, maar wél begin. Wat die Vader deur die Heilige Gees bewerk het moet Hy ná die Nagmaal bevorder deur sy Heilige Gees. Daarvoor word gebid.

Dit is 'n dankgebed. 


\section{SI OTSOM}

Die rituaal van die Nagmaal trek saam in die gemeenskap met die drie-enige God: die Vader uit wie alle genade is, die Seun deur wie alle genade is, die Heilige Gees met wie alle genade in ons in is.

-Ons goeie God ... bekraglig in ons die heil wat Hy aan ons meedeel. Dit (sakramente) is immers sigbare tekens en seëls van 'n inwendige en onsighare saak, en deur middel daarvan werk God in ons deur die krag van die Heilige Gees. Die tekens is dus nie sonder sin en sonder inhoud om ons te bedrieg of te mistei nie; hulle warheid is juis gelee in Jesus Christus, sonder wie hulle geheel en al belekenisloos sou wees.' (Nederlandse Geloofsbelydenis, artikel 33.)

Amen, sê die gelowige: dit is my geloofservaring.

\section{BIBLIOGRAFIE}

ALFORD, H. 1875. The Epistle to the Hebrews. (The Greek Testament vol. IV.) London : Rivingtons. ARND, W.F. \& GINGRICH, F.W. 1957. A Greek-English Lexicon of the New Testament and other early Christian literalure. Chicago : The University of Chicago Press

BAVINCK, H. 1922. Kennis en leven. Kampen: Kok

BIERITZ, K-H. VON. 1981. Abendmahlsverstandnis und Abenmahlpraxis in der Gegenwart. Kerygma und Dogma, 27:242-268. Gottingen : Vanderhoeck \& Ruprecht

BIERITZ, K-H. VON. 1987. Die Taufe als Zeichenhandlung Theologische Literaturzeitung 112(11):786798. Vanderhocek \& Ruprecht

BOELENS, WIM (S.J.). 1979. Tafel en Gasthecr. Baarn : Ten Have

BRUSSARD, J.C. 1949. De Heilige geest en de genademiddelen. (In Bavinck, J.H., red. De Heilige Geest. p. 358-385. Kampen : Kok.)

BURNET, G.B. 1960. The Holy Communion in the Rcformed Church of Scotland 1560-1960. London : Oliver \& Boyd

CALVYN, J. 1889 Uitleg op den Zendbrief van Paulus aan de Romeinen. Vertaal deur A.M. Donner. Leiden : Donner.

CALVYN, J. 1889. Uitlegging op den eersten en tweeden Zendbrief van Paulus aan de Corinthiers. Vertaal deur A.M. Donner. Leiden : Donner

CALVYN, 1890 Uijtlegginhe op den Euangelist Johannes. Verlaal deur H. Franssen. Utrecht : Ten Hoove.

CALVYN, J. 1956. Institutie of onderwijzing in de Christelijke Godsdienst. Uit Latyn vertaal deur A Sizoo. Delft: Meinem

CLARK, N. 1958. An Approach to the Theology of the Sacraments. Studies in Biblical Theology 17. London: SCM Press.

ClEASON, R.N. 1983. Calvin and Bavinck on the Lord's Supper. The Westminster Theological Joumal, XLV (2):273-303. Philadelphia Wesiminster Theological Seminary

COCHRANE, A.C. 1974 Eating and Drinking wilh Jesus An ethical and biblical inquicry. Philadelnhia : The Westminsler Press.

CRAMER, J.A 1942 Zwingly's Sacraments- en Avondmaalsbeschouwing Nieuwe Theologische Studien 
25(4). Wageningen: Veenman

DIX, D.G. 1960. The Shape of the Liturgy London: Dacre Press

GROSHEIDE, F.W. 1932. De eerste hriel van den apostel Paulus aan de kerk te Korinthe (Commentaar op het Nieuwe Testament VII) Amsterdam : Bottenburg.

GROShEIDE, F.W. 1955. De briel aan de Hebreeên. (Commentaar op het Nieuwe Testament.) Kampen : Kok

GUTHRIE, D. 1983 The Leller to the Hebrews. (Tyndale New Testament Commentaries.) Leichester Intervarsity Press.

HENRY, M. 1928. Aan Zijne Tafel. Onderwijzing tot het rechte gebruik van des Heeren Heilig Avondmaal. Kampen : Kok.

HOEK, J. 1925. De Sacramenten bij Paulus en de Hellenistische mysterie-religies. (Proef́skrif: Vrye Universiteit te Amsicrdam.) Zutphen : Nauta. p. 144

HUTCHINS, C.H 1972. The Church and Holy Communion. (In Budianan, C., red.) Evangelical Essays on Church and Sacraments. London : S.P.C.K.)

JONKER, W.D. 1977. Christus, die Middelaar. Preloria : N.G. Kerkboekhandel.

LAMMENS, G. N. 1968. Tot Zijn Gedachtenis. (Proefskrif: Vrye Universiteit Amsterdam.) Kampen : Kok p. 380 .

LLOYD-JONES, D.M. 1975. Romans. An exposition of Chapler 8:17-39. The final perseverance of the saints. Edinburgh : Banner of Truth Trust.

NISCHAN, B. 1984. "The Fractio Panis": A Reformed Communication Practice in Late Reformation Germany. Church History, 53(1):17-29. Chicago : The American Society of Church History.

oDENDAAL, F.F., red. 1988. HAT Verklarende Handwordeboek van die Afrikanse Taal. Johanneshurg: Perskor.

PSALMS. 1987. Die Liturgiese Formuliere. In Afrikaans verıal deur die Bybelvertalers, in opdrag van die Gesamentlike Kommissie verteenwoordigende die drie Afrikaanse Kerke in Suid-Afrika. Potchefstroom : Administratiewe Buro, Gereformeerde Kerke in Suid-Afrika.

RIDDER BOS, H. 1959. Aan de Romeinen. (Commentaas op het Nieuwe Testament.) Kampen : Kok

RUTGERS, F.L. et al. 1913. De herymde Psalmen, met eenige Gezangen, in gebruil bij de Ger eformeerde Kerken in Nederland; al smede hare formulieren van Eenigheid, met de drie oude Gelonfshelydenissen, en hare Liturgie, met Kort Begrip en den Ziekentroost. Maassluis : Biblia.

ROUILLARD, P. 1979. From Human meal to the Christian Eucharist. Worship, 53(1):40-55. Collegeville : Order nf Saint Benedict

SCHUSTER, H. 1960. Das Problem der Sacramente Taufe und Abendmahl. Tubingen : Mohr.

SINODE. 1988. Nolule Vyffe Algemene Sinode van die Gereformeerde Kerke in Suidelike Afrika.

SMIT, D.J. 1982. Die prediking by die Nagmaal. (In Burger, C.W. el al. Riglyne vir Nagmaal prediking Kaapsiad : N.G. Kerk-Uitgewers.)

STIBES, D.M. 1986. Hehrews. (Guthrie, D. et al. reds. New Bible Commentary.) Leicester : Intervarsily Press.

VAN DER LEEUW, G. 1949. Sacramenısi heologie. Nijkerk: Callenhach.

VAN DER MERWE, D.C.S. 1976. Elke Sondag Nagmaal? Poichelstronm : Pro Rege

VAN DER WAL, C. 1971. Amen en Bcamen. Kampen : Kok

VAN STADEN, A」. 1982. Die Nagmaal. Pretoria : Kital.

VAN T SPIJKER, W. 1980. Zijn Verbond en Woorden. Goudrian : De Groot

VAN 'T SPUKER, W. et al. 1980. By Brond en Beker. Goudrian : De Groot.

WENHAM, GJ. 1981. Numbers. An introduction and Commentary. (The Tyndale Old Testament Commentaries.) Leicester : Inlervarsily Press.

WOELDERINK, J.G. 1946. Het Doopsinrmulier. 's Gravenhage : Guido de Brès. 